\title{
STX7 Gene
}

National Cancer Institute

\section{Source}

National Cancer Institute. STX7 Gene. NCI Thesaurus. Code C162435.

This gene plays a role in endocytic vesicle trafficking. 